\title{
MODEL TESTING OF THE "PILE-SOIL" INTERACTION UNDER AXIAL FORCE
}

\author{
${ }^{1}$ Doubrovsky M.P., PhD, Professor, \\ m.doubrovsky@gmail.com, ORCID: 0000-0003-1229-1717 \\ ${ }^{1}$ Dubravina V.O., post-graduate student, \\ dubravina@hotmail.com, ORCID: 0000-0000-0000-0000 \\ ${ }^{1}$ Odessa National Maritime University \\ Mechnikova str, 34, Odessa, 65029, Ukraine
}

\begin{abstract}
Modern marine structures (berths, breakwaters, offshore platforms, etc.) often include steel tubular piles of essential length (80-100 $\mathrm{m}$ and more) that should provide high bearing capacity in case of external axial loads application. Interaction between elements of the system "piled structure - soil media" is not studied sufficiently yet. It relates also to the bearing capacity of the long steel tubular piles of large diameter. One of the interesting peculiarities of long tubular piles behavior is the formation of soil plug at the piles tip. There are a lot of suggestion and methods aimed to increase piles bearing capacity under static pressing load. One of them relates to use of the additional structural element, i.e., the internal diaphragm welded to the internal surface of the pile shaft. Such approach has been applied in some practical cases of marine construction and demonstrated its effectiveness. At the moment there are no researches focused on study of the peculiarities of internal diaphragm application. So proposed research aimed to study two connected processes during steel tubular pile driving: soil plug formation at the tip of the open-end pile and soil behavior under the internal diaphragm fixed inside the tubular pile shaft. To study mentioned processes we provided several series of laboratory experiments fulfilled at the Geotechnical laboratory of the Department "Sea, River Ports and Waterways" in Odessa National Maritime University. In these experiments the model of steel tubular pile has been driven (pressed) into fine sand by mechanical jack. The first series was devoted to determination of the conditions related to the soil plug formation at the pile tip. The next series were aimed to study the influence of the flat rigid diaphragm inside the pile shaft. Obtained experimental results allow to conclude that (a) in the fine sand the plug is formatted at the comparatively early stage of pile installation (in case of our modeling - at the penetration depth of some 4-5 pile diameter); (b) our empirical assessment of the conditions of soil plug formation corresponds to the approaches based on PLR and IFR characteristics; (c) formation of soil plug at the pile tip is followed by decreasing of soil level in the pile shaft relatively its initial value (on completing the plug formation the soil level in the shaft become stable); (d) regarding above mentioned, we may note that in case of use of internal diaphragm on the recommended depth (5-7 pile diameters) there may be no contact between diaphragm and the soil inside the pile (e) application of the diaphragm may lead to increasing of the pile's bearing capacity. It was proposed (and checked by our tests) the technological improvement based on sand filling into space under the internal diaphragm to provide constant diaphragm-soil contact and related soil resistance.
\end{abstract} model tests.

Keywords: steel tubular piles, soil plug, internal diaphragm, pile-bearing capacity, laboratory

Introduction. Modern marine transportation and offshore structures such as deep-water port's berths, oil and gas platforms, raid and offshore fixed single point moorings, submerged stores and others often include steel tubular piles of essential length (80-100 $\mathrm{m}$ and more) as main bearing elements. 
Such tubular piles should provide high bearing capacity in case of external axial loads application [1-4].

One of the interesting peculiarities of long tubular open-end piles behavior is the formation of soil plug at the piles tip [5, 6]. From this point of view, we support known opinion that it is important to study the influence of the soil plug not only on the pile tip bearing capacity but also on soil behavior inside the tubular shaft [4].

In case of necessity, the bearing capacity of long tubular piles may be increased by different methods:

- by driving a pile with a closed end to develop increased end-bearing resistance (but it requires application of too powerful hammers);

- by installing the pile at larger depth in order to reach the bearing soil strata (but such penetrations are often much greater than those required for fixity against lateral loading);

- by grouting beneath the pile toe (but the operations of cleaning-out the pile and grouting are slow and relatively costly);

- by welding a steel plate diaphragm across the interior of the pile in order to increase bearing capacity by use of soil reaction under the diaphragm (such method demonstrated good results on some marine projects and got positive references [4].

In many cases large diameter tubular piles of shelf structures are installed without plugging effect (so called "fully coring mode" [7] or with partial plugging. Therefore, the last approach (closure of the pile shaft) looks rather attractive for deep-water port, marine and offshore engineering but needs detailed consideration and study. So the aim of the work was to determine method's peculiarity, appropriate sphere of application, details of diaphragm construction and proper location along the pile shaft.

Application of internal diaphragm in steel tubular piles. Recommended technology to install the internal diaphragm was described by Tomlinson \& Woodward 2008 [4] (Fig. 1).

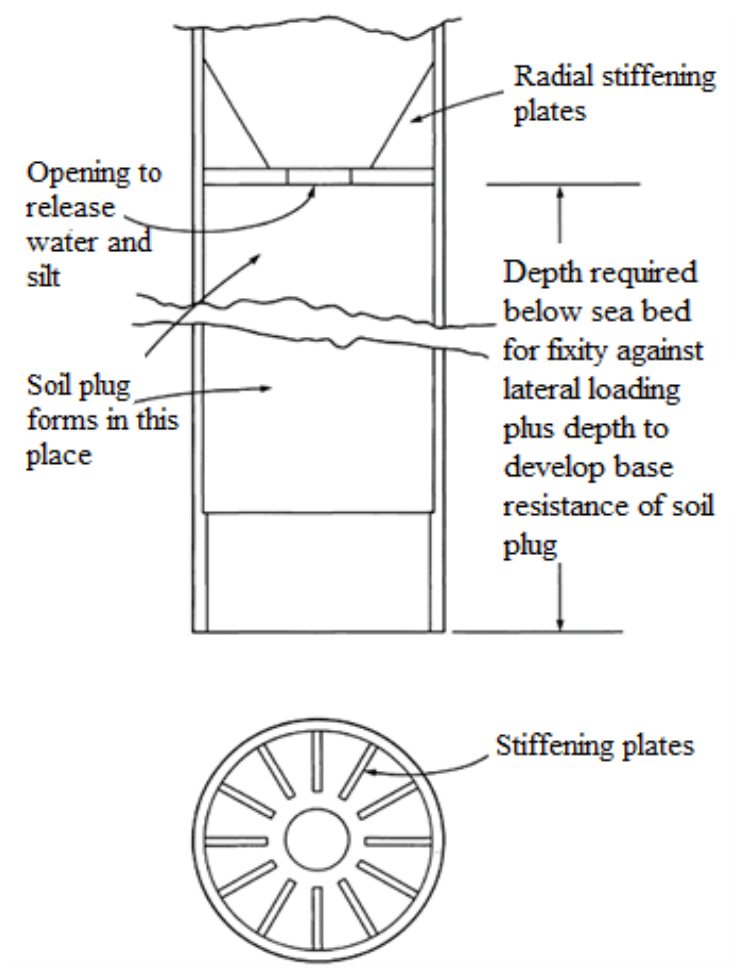

Fig. 1. Steel tubular pile with diaphragm

A hole is necessary in the diaphragm for release of water pressure in the soil plug and to allow expulsion of silt. Stresses on the underside of the diaphragm are high during driving and radial stiffeners are needed. 
According to Tomlinson \& Woodward 2008 [4], the minimum depth above the pile toe for locating the diaphragm is the penetration below seabed required for fixity against lateral loading. There are formulas in some norms allowing determination of the fixity's depth depending on soil properties and pile bending rigidity; roughly, this depth may be determined in the interval of (5-7) d. However, a further penetration is necessary to form the soil plug under the diaphragm by compacting the soil within the plug and to develop the necessary base resistance. Thus, mentioned authors considered two locations for two-soil plugs formation during the tubular pile driving: at the open end of the pile and under the internal diaphragm.

As an example of diaphragm's practical application, we may refer to the piling works at the Hadera coal unloading terminal near Haifa [4]. Open-end piles 1424- and 1524-mm OD were proposed but initial trial driving showed that very deep penetrations, as much as $70 \mathrm{~m}$ below sea bed in calcareous sands, would be needed to develop the required axial resistance. The blow count diagram showed quite low resistance at $36 \mathrm{~m}$ below seabed. Trials were then made of the diaphragm method. A diaphragm with a $600 \mathrm{~mm}$ hole giving $83 \%$ closure of the cross-section was inserted $20 \mathrm{~m}$ above the toe. This increased the driving resistance at $39 \mathrm{~m}$ below seabed and another trial with a $300 \mathrm{~mm}$ hole (95\% closure) gave a higher resistance at $37 \mathrm{~m}$. It was supposed that such improvement of piles bearing capacity was stipulated by soil plug formation below the mentioned diaphragms.

Laboratory model testing. Regarding that obvious effect (increase of the pile bearing capacity) has been achieved by use of the rigid diaphragm, our intention was to study peculiarities of the considered approach providing model static tests in the laboratory conditions. Our aim was to obtain parameters describing considered pile driving process - both qualitative (related to the process in general) and quantitative (characteristic for the applied model pile-soil system) ones. So applied research method in our study was laboratory modeling of "pile-soil" interaction under axial force.

As to the method of pile's installation, we suppose that traditional approaches (use of impact hammer or vibro hammer) are not reliable enough to provide safety of the rigid diaphragm fixed by welding inside the pile shaft and interacted with soil under the diaphragm. In order to avoid dynamic actions upon the diaphragm during pile penetration we prefer to consider a safer but more effective method of pressing load application [6].

To clarify above-mentioned items related to the tubular pile with internal diaphragm, we have started a series of experimental studies in Geotechnical Laboratory of the Department "Sea, River Ports and Waterways" at Odessa National Maritime University (Odessa, Ukraine).

For pile testing, we used soil box of dimensions: width $600 \mathrm{~mm}$, length $750 \mathrm{~mm}$, depth 1100 mm (Figs 2, 3).

For the model of tubular open-end pile, we apply steel pipe $\mathrm{d}=50 \mathrm{~mm}$ external diameter, wall pipe thickness $1 \mathrm{~mm}, l=800 \mathrm{~mm}$ length. To drive the pipe into fine sand mechanical jack has been applied.

The first series of the experiment was aimed to determine conditions of the soil plug formation at the tip of open-end pile model.

Measured parameters (at each stage of load application) were:

- applied vertical axial pressing force (named Load, $F$ on the diagrams);

- pile penetration depth (named Displacement, $t$ on the diagrams);

- soil level inside the pile model (the initial position was fixed when soil levels inside and outside the pile were equal).

In order to describe the process of the model tubular pile plugging we applied:

- earlier proposed IFR (Incremental Filling Ratio) and PLR (Plug Length Ratio) characteristics (for example, recommendations Gudavalli et al. 2013 [7], Brucy et al. 1991 [8], Paik \& Salgado 2003 [9], Lehane \& Gavin 2004 [10] and others).

- assumption that as an evidence of completing of the process of soil plug formation we may consider equal pile vertical displacements and related settlements of the sand surface inside the shaft at each stage of further axial load application. 


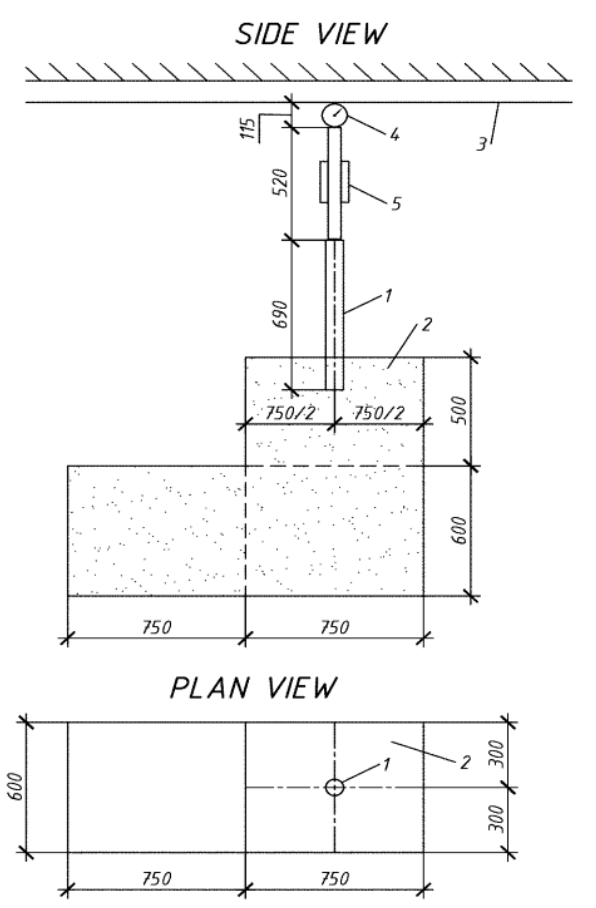

Fig. 2. Scheme of the experiment:

1 - pile model; 2 - sand box; 3 - bearing beam; 4 - force gauge (dynamometer); 5 - jack loading system (telescopic) (all sizes in millimeters)

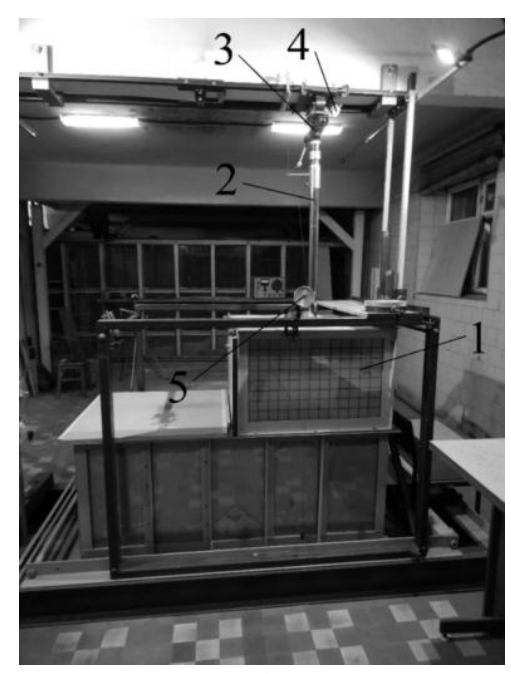

a)

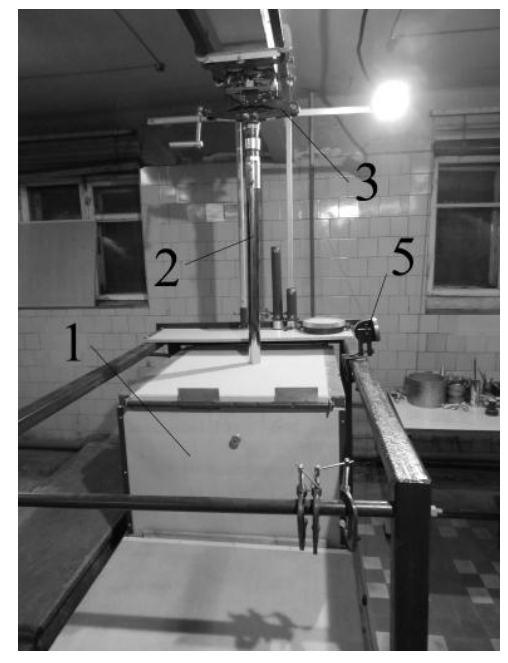

b)

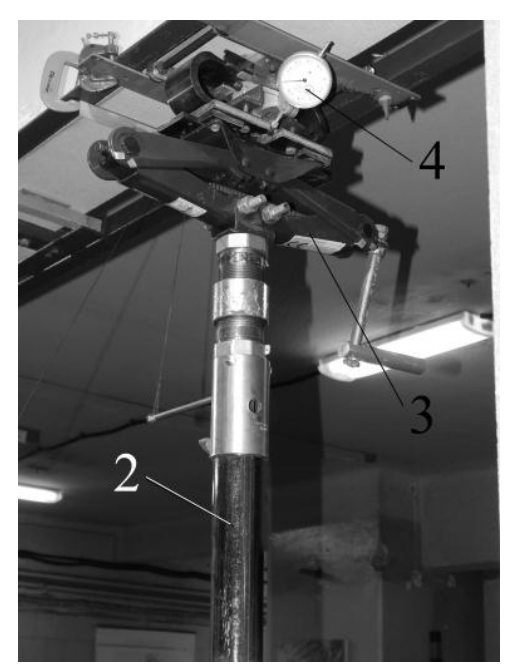

c)

Fig. 3. Experimental system: a - side view; $\mathrm{b}$ - front view; $\mathrm{c}$ - loading system;

1 - soil box; 2 - model pile; 3 - mechanical jack; 4 -dynamometer; 5 -displacement gauge

According to the PLR and IFR diagrams (Fig. 4) at the initial stage of pile installation [till $\mathrm{t}=(1.5$ 2)d] $\mathrm{PLR}=\mathrm{IFR}=100 \%$, i.e. pile is driven according to the "fully coring mode". From the penetration depth of some (4-5)d soil plug length is almost unchanged; average IFR value is stable too. Some IFR fluctuations below the penetration depth $=20 \mathrm{~cm}$ may be explained by technical reasons: resetting of the jack each $20 \mathrm{~cm}$ of the penetration process and corresponding installation of extension tubes.

Similar conclusion may be done on the base of diagrams in Figures 5, 6. Soil level inside the pile shaft become stable at the relative penetration depth (normalized pile displacement) approx. $\mathrm{t} / \mathrm{d}=5-6$ (Fig. 5). Dependencies for $\mathrm{t} / \mathrm{d}$ and $\mathrm{S} / \mathrm{d}$ describing pile and soil displacements also become parallel starting from the $\mathrm{t} / \mathrm{d}=5-6$ and until reaching the pile bearing capacity $=5-6$ (Fig. 6). 

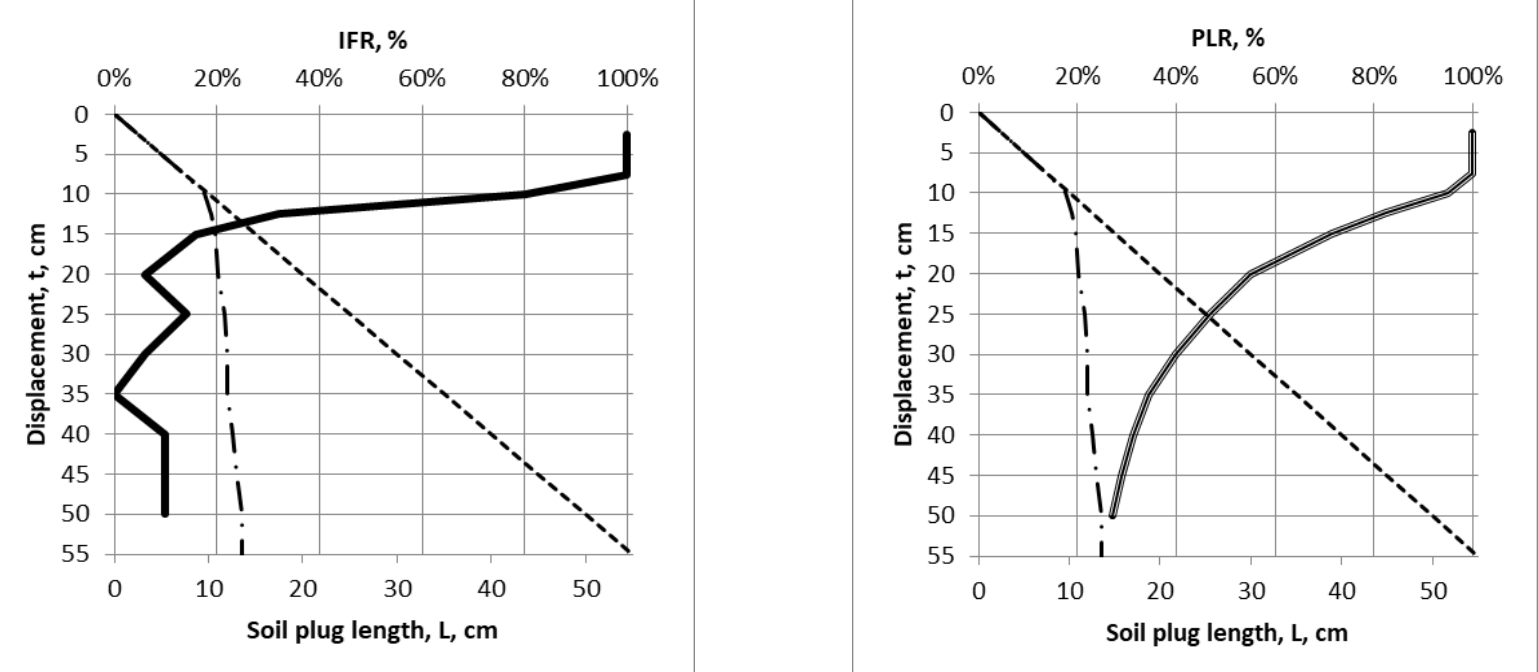

Fig. 4. Typical dependencies for the tests of the first series:

- - $1 ;-\cdot--2 ; \longrightarrow-4$

1 - fully coring mode; 2 - L=L(d); 3 - IFR; 4 - PLR

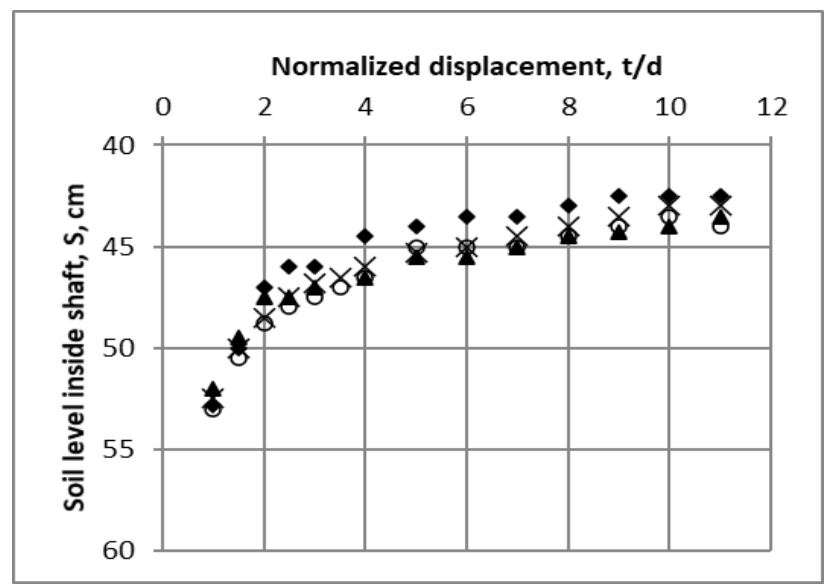

Fig. 5. Results of pile jacking (4 tests): $\mathrm{S}$ - distance between pile top and soil in the shaft

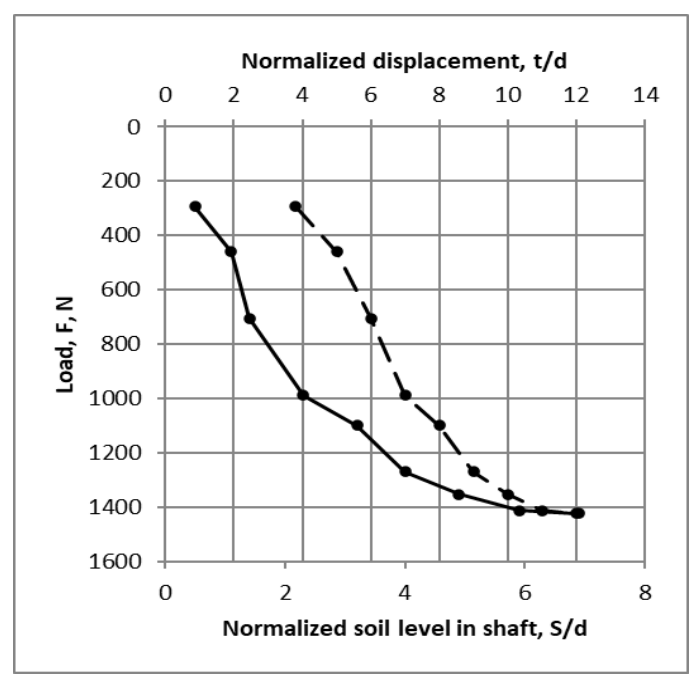

Fig. 6. Results of open-ended model pile jacking (average points of 4 tests):

$$
\rightarrow \bullet-\cdot \quad-\mathrm{t} / \mathrm{d}=\mathrm{t} / \mathrm{d}(\mathrm{F}) ; \rightarrow-\mathrm{S} / \mathrm{d}=\mathrm{S} / \mathrm{d}(\mathrm{F})
$$


Some important research results of the first series of the laboratory experiments may be formulated in the following way:

- in fine sandy soil the plug is formed at the comparatively early stage of pile driving (in the considered case - at the penetration depth of around 4-5 pile's diameters)

- if to locate the internal diaphragm at the recommended depth required for fixity against lateral loading as described above (approx. at the penetration depth of around 5-7 pile diameters), we may meet the situation of no contact between the diaphragm and the soil inside the shaft (clearance space); i.e., the diaphragm does not catch up with soil.

At the second series of the experiment internal diaphragm was fixed at several positions by changing the distance from the tip of the model pile: 0 (closed end); $3 \mathrm{~d}$; $6 \mathrm{~d}$; $9 \mathrm{~d}$ (total length of the pile was equal to 16d). For model pile the diaphragm was produced as a circular steel plate (4 mm thickness), with its diameter corresponded to the inner diameter of the pile.

It has been discovered that due to sand settlements inside the pile shaft during pile installation, there is an empty space under the diaphragm and, correspondingly, no contact between soil and diaphragm. In order to avoid clearance space under the diaphragm and to provide constant contact of the sand with underside of the diaphragm, we applied the diaphragm with several small holes allowing sand filling into the space under the diaphragm. For above mentioned options of the diaphragm location the sand was filled after the pile driving on the depth $3 \mathrm{~d}$, $6 \mathrm{~d}$ and $9 \mathrm{~d}$ correspondingly.

As diagrams presented on Figure 7 demonstrate it, application of the internal diaphragm provides increasing open-end pile bearing capacity. The degree of such increase depends on the diaphragm location. For the considered options of the diaphragm fixing point, the minimal increment of the open-end pile bearing capacity relates to the $3 \mathrm{~d}$ distance between diaphragm and the pile tip and the maximal increment is measured at the $9 \mathrm{~d}$ distance.

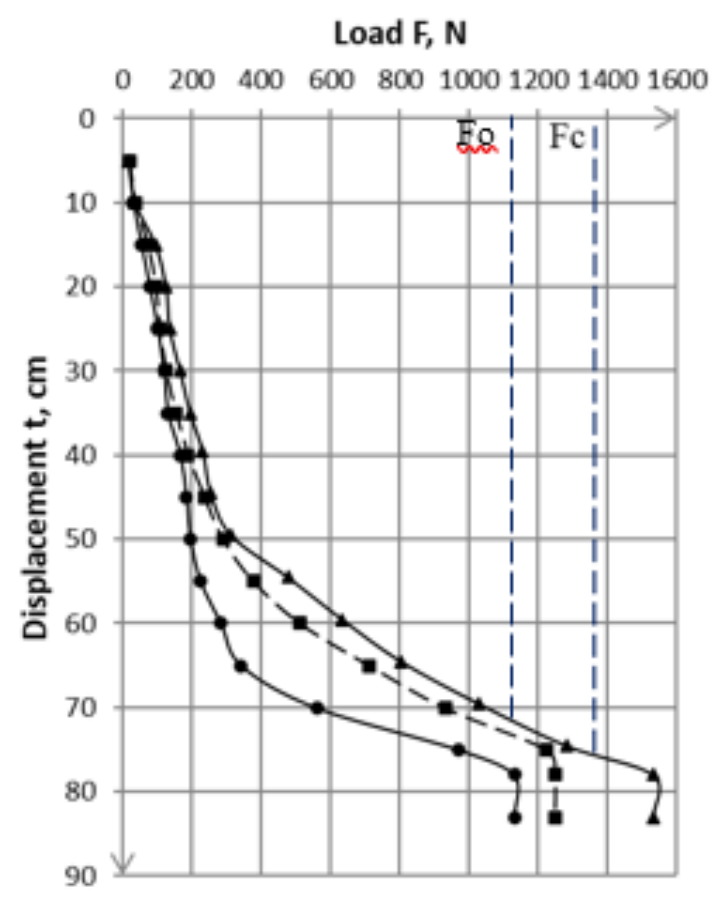

Fig. 7. Dependencies between vertical axial load upon the model pile and its displacements $---\cdot$ - open-end pile; - - closed end;

$\rightarrow-\quad$ diaphragm at $3 \mathrm{~d}$ distance from the pile tip; $---\cdot$ diaphragm at $6 \mathrm{~d}$ distance from the pile tip; $\longrightarrow-$ diaphragm at $9 \mathrm{~d}$ distance from the pile tip;

Fo - open-end pile bearing capacity without diaphragm;

$\mathrm{Fc}$ - closed-end pile bearing capacity 
Perhaps mentioned circumstances may be commented by the following way. The upper plug under the diaphragm may be formed if there is the proper base reaction developed inside the shaft. Such situation may occur if the upper plug (being in the process of formation) meets already formed lower plug. The last transfers additional pressure to the soil under the toe and provokes additional base reaction. Thus, additional external force acts on the plug and increases soil density in it. In fact, after that stage, two plugs are combined and work as one large plug between the diaphragm and pile toe.

It may be explained, particularly, by the fact that for the considered test conditions, approximate driving depth $\mathrm{t}=(4-5) \mathrm{d}$ at the initial stage of pile installation is needed to dense a soil due to the development of the friction forces inside the pile shaft and to form a lower soil plug at the pile tip. If then to apply similar consideration for the follow-on stage of driving process compaction of the soil under the diaphragm due to the similar friction forces, required penetration depth for this stage to form the upper plug may be of similar value (4-5)d. So total distance between pile toe and the diaphragm may be considered as sum of these two parts of the penetration depth, i.e. approx (8-10)d. Such location of the diaphragm may be optimal to form two plugs consecutively and to combine them in one large plug.

Regarding quantitate parameters of open-end pile bearing capacity (Fig. 7), we would like to note that due to the diaphragm's contribution, pile-bearing capacity may be increased (in our tests up to $15-20 \%)$. Another effect consists in possibility to decrease pile driving depth (10-15\%). Obviously mentioned figures should be considered with regard to possible experimental errors stipulated by differences in the reproducibility of the model ground preparation as well as to measurement inaccuracy (perhaps up to $10 \%$ in total).

Regarding scale-effects for the considered problem, it should be noted the following. From the point of view of so called "direct modelling" [11-12], dependencies between limit axial force in the pile $\mathrm{N}_{\text {lim,p }}$ (as well as related displacements $\mathrm{U}_{\text {lim,p }}$ ) and similar parameters of the model may be presented as:

$$
\begin{aligned}
& \frac{\mathrm{N}_{\text {lim }, \mathrm{p}}}{N_{\lim , m}}=C_{L}^{n}, \\
& \frac{\mathrm{N}_{\text {lim, }, \mathrm{p}}}{N_{\lim , m}}=C_{L}^{m},
\end{aligned}
$$

where $\mathrm{C}_{\mathrm{L}}$ - sizes (scales) correlation between prototype and the model;

$n, m$ - parameters depending on soil properties and pile dimensions.

For the conditions of our laboratory model testing (skipping the details of intermediate conversions and calculations) it was determined that related prototype is a tubular pile of diameter $1.0 \mathrm{~m}$ driven up to $10 \mathrm{~m}$ into similar sandy soil. Its bearing capacity (sum of the toe and shaft bearing capacities) is $1723 \mathrm{kN}$. For comparison: calculated value of the prototype bearing capacity according to the recommendation of the related Ukrainian code occurred to be $2020 \mathrm{kN}$ (some $15 \%$ difference).

In addition, for plugging effect assessment we have to consider scale-effects stipulated by influence of internal pile diameter. This aspect is subject to a study for the further investigations.

Conclusion and findings. As obtained from the presented initial series of our experimental studies, rigid diaphragm inside the tubular open-end pile may be a useful element for increasing of the pile's bearing capacity.

Consecutive formation of two soil plugs (lower one formed just at the pile tip and then upper one formed under the diaphragm) leading to their partial or full integration is most effective when the optimal location of the diaphragm inside the pile shaft is provided. From the point of view of pile bearing capacity under axial compressive load and for the considered experimental conditions, such proper distance between the pile tip and internal diaphragm occurred to be around $9 \mathrm{~d}(\mathrm{~d}-$ pile diameter).

As demonstrated by our tests, during pile jacking process there is a possibility of clearance space between the diaphragm and soil inside the pile shaft (no contact situation). For real 
construction site conditions and inhomogeneous soil base it is complex task to check proper diaphragm-soil contact and their interaction or to determine clearance space formation under the diaphragm. That's why it is proposed (and checked by our tests) the technological improvement based on sand filling into space under the internal diaphragm to provide constant diaphragm-soil contact and related soil resistance. Such approach guarantees force interaction between the internal diaphragm and the soil inside the shaft via filled sand and may simplify calculation scheme of such interaction (the last is a task of future development of the considered problem).

Improvement of the pile effectiveness determined by experimental modeling for the abovementioned pile-soil conditions provides $15-20 \%$ increasing of the bearing capacity or 10-15\% reduction of the driving depth.

Presented experimental studies should be continued and developed in order to study installation peculiarities of piles with diaphragm by pressing technologies. Also, it looks prospective to investigate influence of internal diaphragm's design (different from the considered flat plate option).

\section{References}

[1] M. Doubrovsky, R. Pereiras, "Single point fixed moorings for Ukrainian shelf and seaports: problems and prospects of development", Herald of the Odessa National Maritime University, no. 41, pp. 123-133, 2014.

[2] M. Doubrovsky, A. Gerashchenko, I. Dobrov, O. Dubrovska, "Piled structures for marine transportation facilities: innovative structures and technologies", Proceedings of the Second International Conference "Challenges in Geotechnical Engineering 2017», 2017, pp. 104-105.

[3] M. Doubrovsky, A. Gerashchenko, I. Dobrov, O. Dubrovska, "Innovative Design and Technology Solutions for Development of Port and Offshore Pressed-in Piled Structures", Proc. of the First International Conference on Press-in Engineering, Kochi, Japan, 2018.pp. 91-99.

[4] M. Tomlinson, J. Woodward, Pile design and Construction Practice, Fifth edition, Taylor \& Francis, N.Y. 2008.

[5] M.F. Randolph, E.C. Leong, G.T. Houlsby, "One-dimensional analysis of soil plugs in pipe piles", Geotechnique, vol.41, no.4, pp. 587-598, 1991.

[6] D.J. White, A.D. Deeks, Y. Ishihara, "Novel piling: axial and rotary jacking", Proc. of the 11th International Conference on Geotechnical Challenges in Urban Regeneration, London, UK, CD, 2010, $24 \mathrm{p}$.

[7] S.R. Gudavalli, O. Safaqah, H. Seo, "Effect of soil plugging on Axial Capacity of OpenEnded Pipe Piles in Sands", Proceedings of the 18-th International Conference on Soil Mechanics and Geotechnical Engineering, Paris, France, 2013, pp. 1487-1490.

[8] F. Brucy, J. Meunier, J.F. Nauroy, "Behavior of pile plug in sandy soils during and after driving", In: Proceedings of 23rd Annual Offshore Technology Conference, Houston, 1, pp. 145-154, 1991.

[9] K. Paik and R. Salgado, "Determination of bearing capacity of open-ended piles in sand", Journal of Geotechnical and Geoenvironmental Engineering, 129(1), pp. 46 - 57, 2003.

[10] B.M. Lehane and K.G. Gavin, "Discussion of Determination of bearing capacity of openended piles in sand", Journal of Geotechnical and Geoenvironmental Engineering, vol. 130, no. 6, pp. $656-658,2004$.

[11] V.A. Florin, Fundamentals of Soil Mechanics: Volume 1 General Relationships and State of Stress Caused By Foundation Loads. Moscow, National Technical Information Service, 1961.

[12] P.L. Ivanov, Soils and bases of the hydraulic structures. Textbook. Moscow, High School. 1985. 


\title{
МОДЕЛЬНІ ДОСЛІДЖЕННЯ ВЗАСМОДІї «ПАЛЯ-ГРУНТ» ПРИ ПРИКЛАДАННІ ОСЬОВОЇ СИЛИ
}

\author{
${ }^{1}$ Дубровський М.П., д.т.н., професор, \\ m.doubrovsky@gmail.com, ORCID: 0000-0003-1229-1717 \\ ${ }^{1}$ Дубравіна B.O., аспірантка, \\ dubravina@hotmail.com, ORCID: 0000-0000-0000-0000 \\ ${ }^{1}$ Одеський національний морський університет \\ вул. Мечникова, 34, м. Одеса, 65029, Україна
}

\begin{abstract}
Анотація. Сучасні морські споруди (причали, хвилеломи, морські платформи та тощо) часто включають сталеві трубчасті палі суттєвої довжини (80-100 м та більше), які повинні забезпечувати високу несучу здатність при прикладенні зовнішніх осьових навантажень. Взаємодія між елементами системи «палева конструкція-грунтове середовище» ще недостатньо вивчене. Це стосується також несучої здатності довгих сталевих трубчастих паль великого діаметру. Одна 3 цікавих особливостей поведінки довгих трубчастих паль виникнення грунтової пробки на кінці палі. Раніше були запропоновані різні методи підвищення несучої здатності паль при статичному вдавлюючому навантаженні. Один 3 них стосується використання додаткового конструктивного елементу - внутрішньої діафрагми, привареної до внутрішньої поверхні стовбуру палі. Такий підхід застосовувався в деяких практичних випадках морського будівництва та продемонстрував свою ефективність. На даний момент немає досліджень, що направлені на вивчення особливостей застосування внутрішньої діафрагми. Наше дослідження було направлене на вивчення двох взаємопов'язаних процесів при зануренні сталевої трубчастої палі: утворення грунтової пробки на кінці відкритої палі та поведінка грунту під внутрішньою діафрагмою, закріпленої всередині стовбуру трубчастої палі. Для вивчення вказаних процесів ми провели декілька серій лабораторних досліджень, виконаних в геотехнічній лабораторії кафедри «Морські, річкові та водні шляхи» Одеського національного морського університету. В цих експериментах модель сталевої трубчастої палі занурювалась (вдавлювалась) в дрібний пісок механічним домкратом. Перша серія була присвячена визначенню умов, пов'язаних 3 утворенням грунтової пробки на кінці палі. Подальші серії були направлені на вивчення впливу жорсткої діафрагми всередині стовбуру палі. Отримані експериментальні результати дозволяють зробити висновок, що (а) в дрібному піску пробка формується на відносно ранній стадії занурення палі (у випадку нашого моделювання - на глибині занурення порядку 4-5 діаметрів палі); (б) наша емпірична оцінка умов формування грунтової пробки відповідає підходам, що базуються на характеристиках PLR та IFR; (в) утворення грунтової пробки на кінці палі супроводжується зниженням рівня грунту в стовбурі палі відносно його початкового значення (по закінченню формування пробки рівень грунту в стовбурі стає стабільним); (г) у зв'язку з вищенаведеним, відмітимо, що при використанні внутрішньої діафрагми на рекомендованій глибині (5-7 діаметрів палі) може не бути контакту між діафрагмою та грунтом всередині палі; (д) застосування жорсткої плоскої діафрагми може привести до зростання несучої здатності палі. Запропоновано (i перевірено нашими дослідженнями) технологічне вдосконалення, засноване на засипці піском простору під внутрішньою діафрагмою для забезпечення постійного контакту діафрагми 3 грунтом i відповідного опору грунту.
\end{abstract}

Ключові слова: сталеві трубчасті палі, грунтова пробка, внутрішня діафрагма, несуча здатність палі, лабораторні модельні дослідження. 


\title{
МОДЕЛЬНЫЕ ИССЛЕДОВАНИЯ ВЗАИМОДЕЙСТВИЯ «СВАЯ-ГРУНТ» ПРИ ПРИЛОЖЕНИИ ОСЕВОЙ СИЛЫ
}

\author{
${ }^{1}$ Дубровский М.П., Д.Т.Н., профессор, \\ m.doubrovsky@gmail.com, ORCID: 0000-0003-1229-1717 \\ ${ }^{1}$ Дубравина В.А., аспирантка, \\ dubravina@hotmail.com, ORCID: 0000-0000-0000-0000 \\ ${ }^{1}$ Одесский национальный морской университет \\ ул. Мечникова, 34, г. Одесса, 65029, Украина
}

\begin{abstract}
Аннотация. Современные морские сооружения (причалы, волноломы, морские платформы и т.д.) часто включают стальные трубчатые сваи существенной длины (80-100 м и более), которые должны обеспечивать высокую несущую способность при приложении внешних осевых нагрузок. Взаимодействие между элементами системы «свайная конструкциягрунтовая среда» еще недостаточно изучено. Это касается также несущей способности длинных стальных трубчатых свай большого диаметра. Одна из интересных особенностей поведения длинных трубчатых свай - образование грунтовой пробки на конце сваи. Ранее были предложены различные методы повышения несущей способности свай при статической вдавливающей нагрузке. Один из них заключается в использовании дополнительного конструктивного элемента - внутренней диафрагмы, приваренной к внутренней поверхности ствола сваи. Такой подход применялся в некоторых практических случаях морского строительства и продемонстрировал свою эффективность. На данный момент нет исследований, направленных на изучение особенностей применения внутренней диафрагмы. Наше исследование было направлено на изучение двух взаимосвязанных процессов при погружении стальной трубчатой сваи: образование грунтовой пробки на конце открытой сваи и поведение грунта под внутренней диафрагмой, закрепленной внутри ствола трубчатой сваи. Для изучения указанных процессов мы провели несколько серий лабораторных исследований, выполненных в геотехнической лаборатории кафедры «Морские, речные и водные пути» Одесского национального морского университета. В этих экспериментах модель стальной трубчатой сваи погружалась (вдавливалась) в мелкий песок механическим домкратом. Первая серия была посвящена определению условий, связанных с образованием грунтовой пробки на конце сваи. Дальнейшие серии были направлены на изучение влияния жесткой диафрагмы внутри ствола сваи. Полученные экспериментальные результаты позволяют сделать вывод, что (а) в мелком песке пробка формируется на относительно ранней стадии погружения сваи (в случае нашего моделирования - на глубине погружения порядка 4-5 диаметров сваи); (б) наша эмпирическая оценка условий формирования грунтовой пробки отвечает подходам, основанным на характеристиках PLR и IFR; (в) образование грунтовой пробки на конце сваи сопровождается понижением уровня грунта в стволе сваи относительно его начального значения (по окончании формирования пробки уровень грунта в стволе становится стабильным); (г) в связи с вышеизложенным, отметим, что при использовании внутренней диафрагмы на рекомендованной глубине (5-7 диаметров сваи) может не быть контакта между диафрагмой и грунтом внутри сваи; (д) применение жесткой плоской диафрагмы может приводить к увеличению несущей способности сваи. Предложено (и проверено нашими исследованиями) технологическое усовершенствование, основанное на засыпке песком пространства под внутренней диафрагмой для обеспечения постоянного контакта диафрагмы с грунтом и соответствующего сопротивления грунта.
\end{abstract}

Ключевые слова: стальные трубчатые сваи, грунтовая пробка, внутренняя диафрагма, несущая способность сваи, лабораторные модельные исследования.

Стаття надійшла до редакції 13.05.2021

Bulletin of Odessa State Academy of Civil Engineering and Architecture, 2021, no. 83, page 102-111 